\title{
THE EMPLOYMENT RIGHTS OF DISABLED PEOPLE IN THE REPUBLIC OF MACEDONIA
}

\author{
Daniela Koceva, master`s student at the Faculty of Law \\ at University "Goce Delchev"-Stip, Macedonia, \\ e-mail: daniela.koceva79@yahoo.com
}

Professional Paper

doi:10.5937/jouproman4-11301

\begin{abstract}
The analyses of the legal framework concerning the employment rights of the disabled people in the Republic of Macedonia is a significant research challenge because of its importance regarding the employment rights regulation of the disabled people in all.

When analyzing the regulation regarding the disabled people, the editing of their rights is of great importance as a source and promoter of many crucial changes and value components when creating a democratic society with no discrimination.

Considering this, the influence of the degree of respecting the value principles and standards is particularly emphasized along with the human rights and freedom of the disabled people when it comes to the development of the democracy and the rule of law.

The purpose of this paper is to analyze the Macedonian legal framework for the employment rights of the disabled people and to present the provisions of the most important legal acts concerning this subject.
\end{abstract}

Key words: discrimination; strategy; law

\section{Introduction}

The disability, in medicine terms, is an individual problem which is directly connected to an illness, injury or some other health damage which requires medical help and care provided by professionals.

According to the social disability approach, the system barriers, the negative attitudes and beliefs, and the society exclusion are the determination factors which define who is disabled and who is not. Regarding this approach, some people have physical, intellectual, sensory or psychological differences which sometimes cause individual disability.

These elements don't necessarily lead to disability if the society succeeds in taking care and including them despite their differences.

It is certain that some individual differences lead to disability, but this cannot be the reason why some individuals or groups of people are excluded. It is necessary that every country should guarantee the legal framework for the employment rights of the disabled people.

\section{Definition of a disabled person}

According to the Law on employment of the disabled people, a disabled person is considered:

- a person with damaged sight, hearing, voice and speech;

- a physically disabled person;

- a person with intellectual disabilities; and

- a person with multiple disabilities, which due to their level of disability result with specific work needs.

According to the Law on employment of the disabled people, a disabled person is considered a disabled worker with remained or reduced working ability and if the person is registered as an unemployed person in the Employment Agency in the Republic of Macedonia.

In relation to the terms used by the Revised national strategy for equal rights of the disabled people of the Republic of Macedonia (2010-2018) [3], we state that the disability is determined according to the preamble of the convention for the rights of the disabled people. 
Therefore, the disability is caused by the interaction of the disabled people with the surrounding barriers and difficulties that are reflected in certain society attitudes. These difficulties complicate the effectiveness and the involvement of the disabled people in the system. Regarding the Convention for the rights of the disabled people (article 1, paragraph 2), and according to this strategy, a disabled person is a person that has long-term physical, intellectual, mental and sensory disorders which can have negative effect on the overall efficient participation of these people in the society. [3]

2. The Legal framework of the employment rights of the disabled people in the Republic of Macedonia

This paragraph includes an analyze of the following legal acts:

- Law on employment of the disabled people in the Republic of Macedonia, and

- Revised National Strategy for equal rights of persons with disabilities (2010-2018), of the Republic of Macedonia.[3]

\subsection{Law on employment of the disabled people in the Republic of Macedonia}

The Law on employment of the disabled people ("Official Gazette of the Republic of Macedonia" no. 87/05) [1], includes special conditions for employment and terms of working of disabled people, when:

- they independently work as a sole proprietor;

- they are employee or an employer, they work in public administration, local self-government, public enterprises, agencies and other public institutions;

This Law also includes the conditions for establishing and managing a trading company for employment of disabled people - protected company. The Law on employment for disabled people provides many measurements for improving the working and employment conditions for the disabled people such as:

- providing irreversible funds for indefinite employment for an unemployed disabled person;

- adaptation at the workplace where the disabled person would work and acquiring appropriate equipment according the criteria set by the Minister of Labor and Social Policy;

- tax exemption and providing contribution funds;

- financial support.

There is a special Commission for estimating the working ability of the Pension and disability insurance in the Republic of Macedonia which determines the disability based on a request by a disabled person, a parent or guardian, unless the disability of the person was determined by another competent authority.

The Article 4 of the Law on employment for disabled people states that the Minister of labor and social policy creates a Commission in the Ministry of labor and social policy, and also defines the composition of the Commission by a legal act. This Commission defines everything that the disabled person can perform at the workplace. The Law on employment for disabled people states that the operating funds of this Commission are provided by a Special Fund.

According to Article 5 of the Law on employment for disabled people, the employer cannot employ or transfer a disabled person from one to another work place, if that person does not fulfill the general and specific conditions i.e. the person is not capable of completing the work obligations and does not have a permission of the Commission for completing these obligations. If the disabled person is permitted by the Commission, he/she can work as an employer or an employee. 
The disabled person is entitled to salary meaning that the employer is obliged to provide the disabled person with a salary according to the law, collective agreement and employment contract (Law on employment of disabled people in the Republic of Macedonia, article 6). The salary of the disabled person should be transferred to a current account or savings account, and it can be withdraw only by disabled person, the spouse, a parent or a guardian.

When employing a disabled person, every employer has an obligation to create adequate working conditions and to adapt the workplace in accordance with the workplace itself, the type and degree of education, and the type and degree of the disability of the employed disabled person (Law on employment of disabled people in the Republic of Macedonia, article 7).

The employed disable person who has a damaged sight, hearing, voice and speech, who is physically disabled, intellectually disabled, with multiple disabilities which due to their level of disability result with specific work needs, is going to be exempted from the personal income tax (Law on employment of disabled people in the Republic of Macedonia, article 9). The Law on employment for disabled people states that the income funds for pension and disability insurance, the health insurance income and the employment income of these people are provided by the Budget of the Republic of Macedonia. The Budget of the Republic of Macedonia provides funds in the basis of the amount of two net monthly salaries in the Republic of Macedonia in the previous month. In case the net salary exceeds this amount, the income funds are paid by the employer of the disabled person.

The working financial support covers both the benefits that the disabled person receives while working independently as a sole proprietor and the Special Fund finances for the protected company (Law on employment of disabled people in the Republic of Macedonia, article 10).
The protected companies are established as trading company in order to employ disabled people. The Law states that the protected company can only be established if it employs at least five people for an indefinite period of time. $40 \%$ of the total number of employees must be disabled people out of which at least half must have a disability stated by the Law on employment for disabled people (Law on employment of disabled people in the Republic of Macedonia, article 11). Each newly established protected company is obliged to employ all the workers considering the first worker who has a contract for an indefinite period of time. This must be completed in 90 days. In case this is not respected, the company cannot gain the protected company status, and in that period of time no one from the close family, including the founder himself, don't have the right to establish a new protected company. In case the protected company violates the required number of disabled employees in accordance with the total number of workers for an indefinite period of time more than three times in consecutive two years, it is no longer considered a protected company and cannot work as such in the next five years. In this period neither the founder nor a close family member can establish a new protected company. The protected company is exempted from the income tax and all taxes from profits.

The disabled person has the right to be trained for certain practice work in accordance with the employer needs and the disabled person abilities. The Employment agency of the Republic of Macedonia is responsible for the training of the disabled people. The disabled person, who is not qualified to complete certain tasks at the workplace, will be assigned to training by the employer himself (Law on employment of disabled people in the Republic of Macedonia, article 14). 
The Employment agency of the Republic of Macedonia is obliged to keep record of the unemployed disabled people in the country, whereas the employment of the disabled people is provided by the list of the registered unemployed disabled people in the Agency (Law on employment of disabled people in the Republic of Macedonia, article 15). The disabled person can be employed for a position for which that person is qualified, but he/she can also be employed or transferred to another workplace if he/she completes the general and specific conditions or is trained to do that type of job, and if that person has a permission to complete the tasks of that certain workplace.

The disabled person who is trained does not have an employee status for the employer unless he/she is a worker at same company that provides the training.

According to Article 18 of the Law on employment for disabled people, the financing of the requirements and working conditions for disabled people, the adaptability at the workplace and the equipment supply, is provided by $5 \%$ of the total employment income of the Agency (Special Fund) not later than $30^{\text {th }}$ of every previous month.

The disabled person who operates as a sole proprietor, a protected company or another legal entity, must submit a request for funds from the Special Fund to the Agency's Board. The legal entity that is not a protected company can be provided with funds from the Special Fund for a disabled employee for an indefinite period of time and also for adaptation to the workplace where the disabled person would work. The protected company can be provided with funds from the Special Fund for a disabled employee for an indefinite period of time, for adaptation to the workplace where the disabled person would work, and also for equipment supply. The disabled person who operates as a sole proprietor can be provided with funds from the Special Fund for his/her employment for an indefinite period of time, for adaptation to the workplace where the disabled person would work, and also for equipment supply. The Agency's Board adopts a decision for allocating resources from the Special Fund every 60 days. A complaint against this decision can be submitted in the following 8 days from receiving the decision. This complaint is addressed to the Minister of labor and social policy (Law on employment of disabled people in the Republic of Macedonia, article 19). The Law on employment for disabled people states that the resources from the Special Fund are nonrefundable only if: [4]

- the employment of the disabled person for an indefinite period of time with a total amount of 20 average salaries in the Republic of Macedonia for the year before the employment i.e. 40 average salaries in the Republic of Macedonia for the year before the employment for a totally blind person (practically blind person) and physically disabled person who needs a wheelchair;

- the workplace adaptability in the amount of 100000 denars which can also be used if required by the technically-technological process or the type and degree of the disability of the disabled person; and

- the equipment supply in the amount of 200 average salaries in the Republic of Macedonia in the previous year, where the applicant in the calculated value of the program should participate with $20 \%$ own contribution (own funds, bank loan or personal funds of the company owner).

The amount of the provided funds can be up to the property value and the permanent capital registered in the books of the applicant (initial investment, equipment, construction and business facilities, stores, etc). 
The applicant must also have a mortgage in 2:1 ration with the bank guarantee in accordance with the provided funds. The mortgage or the bank guarantee must be at least three years valid.

In accordance with Article 24 of the Law on employment for disabled people in the Republic of Macedonia the surveillance of the provision implementation of this Law is executed by the Ministry of labor and social policy in the Republic of Macedonia, while the inspection surveillance of the provision implementation of this Law which refer to the special working conditions of the disabled person are provided by the State Labor Inspectorate of the Republic of Macedonia.

\subsection{National strategy for equal rights of the disabled people of the Republic of Macedonia (2010- 2018)}

When it comes to the employment of the disabled people, the Government of the Republic of Macedonia has adopted a National strategy for equal rights of the handicapped people of the Republic of Macedonia on $24^{\text {th }}$ December 2001 (Official Gazette of the Republic of Macedonia, no 101/01) [2]. This National strategy is based on the detailed analysis and the indication of necessity when adopting appropriate decisions by the Government for protection, rehabilitation, education, employment and training of the disabled people. The Government follows the commitments for respecting the human rights and creating a society with no discrimination. In that sense, the Government has ratified many international documents such as the National strategy for equal rights of the handicapped people of the Republic of Macedonia. This Strategy is complemented by the Strategy for equal rights of the disabled people of the Republic of Macedonia.
This Strategy is based on the following legal acts:

- The Universal declaration of human rights;

- The Convention on the rights of the child;

- The UN Convention on the rights of the disabled people;

- The standard rules for equal opportunities for the disabled people;

- The Declaration of the rights of the disabled people;

- The Declaration of the rights of the people with intellectual disabilities;

- The Declaration of social progress and development;

- The International convention on the protection of the rights of every worker, migrant, and their families;

- The Convention on eliminating every form of discrimination of women;

- The Principles for protection of the people with mental disorders and for improvement and protection of the mental health and other UN legal acts;

- The Agreements and recommendations accepted by the International labor movement, from the educational scientific and cultural organizations of the United Nations, the World Declaration on Education for all people, the acts of the World Health Organization, the UN Children's Fund, the World Programme of activities for the Decade of Disabled Persons (19831992), the European Convention for human rights, the European social charter and the revised European social charter, the Action plan of the Council of Europe for promoting the rights and full participation in society for persons with disabilities, enhancing the quality of life of people with disabilities in Europe 2006-2015. 
The purpose of the Strategy is to improve the position of the disabled people to a position of rightful citizens who will benefit from all the rights that belong to them. This Strategy is supposed to support the organizations for disabled people, and their participation in the decision making process regarding specific questions concerning the disabled people. The Government has formed a national coordination body for equal rights of the disabled people in the Republic of Macedonia. The participants in this body are people from national disability organizations, institutions, and ministries in charge of this area. One of the principal tasks of this Strategy is to achieve development of policies, programs, and measurements in the area of employment and other areas which will further provide equal possibilities which will enhance the personal development, independence and activity in all areas of living. This Strategy also contains a part which refers to the professional and working orientation and employment. This part concerns questions of the area of equal possibilities for employment of the disabled people. Not providing appropriate conditions is considered as discrimination, and the actual standards state that disability discrimination must be forbidden regarding all questions referring to the employment, recruiting, engaging, and also carrier advancing, continuing of the employment, as well as secure and healthy working conditions. This part is also included in Article 27 of the Convention on the rights of disabled people. In the Republic of Macedonia the legal regulation stipulates the possibilities and activities for employment of the disabled people. The Strategy emphasizes certain purpose regarding the security of equal employment possibilities of the disabled people through development and implementation of decisions which are based on the needs and abilities.

In order to fulfill the stated purposes, the Strategy suggests taking measurements such as:
- Raising the level of competence and knowledge of all social actors directly involved in the process of creation and implementation of employment policies for disabled people;

- The development of the expert and professional training through certain forms of training, expert training, further education and other forms of learning through the work of disabled people;

- Strengthening the motivation of disabled people due to their involvement in the working process through the promotion of the principle for active living;

- Strengthening the role and responsibility of the social partners due to an overall approach in the field of employment of disabled people;

- Developing and establishing an information system for employment of the disabled people and the employers;

- Developing mechanisms for assessment of the working skills and needs based on international standards;

- Development of an economy model in line with the Active employment measures through the operational plans for employment of the Government;

- Development of the mechanisms and resources for professional rehabilitation.

The Ministry of labor and social policy and the Ministry of education and science in cooperation with the National consult for disability organizations and other nongovernmental organizations are responsible for these measurements in accordance with the Strategy. It is decided that the implementation of this Strategy will be monitored through evaluation and surveillance by the National coordinating body for equal rights of the disabled people in the Republic of Macedonia. 
This body aims to supply coordinating mechanisms for regulating and practicing those policies that directly or indirectly concern the disabled people. After completing the action plans of certain measurements, the National coordinating body forms a commission which will follow research and develop the programs for disabled people in accordance with the international legal acts in these areas. The relevant ministries are obliged to take certain measurements for implementing this strategy in line with their legal areas, and to submit an annual report to the Government. The Bureau of social policy in cooperation with the Ministry of labor and social policy is responsible for the evaluation, protection, and monitoring of the Strategy. The Bureau should also submit an annual report to the Government.

\section{Conclusion}

The existence of strong and quality legal framework for the rights of the disabled people is a basis and guarantee for the presence and the democracy functioning in a modern society.

The analyzed legal acts refer to the rights of the disabled people when it comes to their employment. It can be stated that the measurements predicted by the legal acts are a great opportunity for the disabled people to secure their existence and to become independent and successful people.

In conclusion, the Law on employment of the disabled people includes decisions that aim to use the working ability of the disabled people and their appropriate competition at the open labor market.

To sum up, the benefits for the companies employing disabled people are stated. These benefits can be noted through tax and social income exemptions. Apart from these exemptions, there is financial support for the companies that directly aims to improve and facilitate the working process for the disabled people.

\section{References}

[1] Law on employment of disabled people in the Republic of Macedonia (Official Gazette of the Republic of Macedonia no.87/05) Retrieved from: Last visited: 20.06.2016.

[2] Law on employment of disabled people in the Republic of Macedonia (Official Gazette of the Republic of Macedonia, no 101/01). Retrieved from: Last visited: 20.06.2016.

[3] Revised National strategy for equal rights of the disabled people of the Republic of Macedonia (2010-2018). Retrieved from: http://mtsp.gov.mk/WBStorage/Files/FINALNA \%20Revidirana\%20Nacionalna\%20Strategija.p df; Last visited: 20.06.2016.

[4] Retrieved from: http://www.pravdiko.mk/povolnosti-privrabotuvane-na-invalidni-litsa/; Last visited: 20.06.2016.

[5] Retrieved from: http://netpress.com.mk/spasovso-noviot-zakon-dopolnitelni-prava-za-licataso-invalidnost/; Last visited: 20.06.2016.

[6] Retrieved from: http://www.pravdiko.mk/predlog-izmeni-nazakonot-za-vrabotuvane-na-litsa-soinvalidnost/; Last visited: 20.06.2016. 